\title{
Differential Investment Performance In South Africa Based On Gender
}

Gizelle Willows, University of Cape Town, South Africa Darron West, University of Cape Town, South Africa

\begin{abstract}
Research has shown that, as a result of certain behavioural biases, individuals do not always make investment decisions in such a way as to maximise their expected utility. These biases have also been observed to manifest differently within gender: men are more overconfident, they display higher risk tolerances and they exhibit stronger self-efficacy and self-attribution biases. The trading behavior and resultant returns of 19,021 individual investors from a South African investment house were analysed over a five-year period (1 January 2007 - 31 December 2011). The results showed a statistically significant negative correlation between trading frequency and investor return. While there is no statistically significant difference in the returns earned by men and women; men trade more and have higher variances of returns than women. The data suggests that, on a risk-adjusted basis, women are better investors than men.
\end{abstract}

Keywords: Gender; Men And Women; Behavioral Biases; Trading Frequency; Variances Of Return

\section{INTRODUCTION}

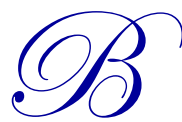

ehavioral finance has grown in popularity over the last decade and research in the field has gathered considerable momentum. Of particular interest to this study is that some researchers have shown that behavioral biases exhibit differently in men and women. In particular, men have been found to be less risk-averse and more overconfident than women, and that overconfidence leads to overtrading. Most existing research concludes that overtrading lowers returns, but there is insufficient consistent evidence to support this assertion.

Limited studies have been performed to test these biases in emerging markets. This study contributes to the international body of knowledge available on investor behaviour by attempting to test the theoretical findings in the South African market. The effect of trading frequency on investor return as well as a comparison of the trading frequency and investor returns earned by men and women will be analysed.

The remainder of this paper is structured as follows. Section 2 reviews prior literature on the development of behavioral finance and associated behavioural biases. Section 3 presents the data and discusses the methodology adopted in testing the hypotheses. The results are presented in Section 4 while Section 5 concludes.

\section{LITERATURE REVIEW}

The efficient markets hypothesis (Fama \& Macbeth 1973; Fama \& French 1992) presumes that individuals will behave and make decisions in such a way as to maximise their expected utility. However, this theory has been unable to explain a number of empirical patterns, such as the stock market bubbles in the U.S., Taiwan and Japan (Ritter, 2003) as well as the financial crisis of 2008/9 (see Annexure B). Behavioral finance offers some explanations for these events, predicated on the assumption that individuals are not fully rational (Ritter, 2003). 
Pompian and Longo (2004), administered a Myers-Briggs Type Indicator ${ }^{\circledR}$ personality test and questionnaire to 100 investors in an attempt to uncover investor biases. The results showed that men and women are considerably different in their susceptibility to various behavioral biases. This finding is supported by Beyer (1998) and Estes and Hosseini (1988).

This review will discuss the behavioral biases that display the strongest differences between men and women namely overconfidence (Barber \& Odean, 2001), self-efficacy (Barber \& Odean, 2000, 2001; Rammstedt \& Rammsayer, 2002), self-attribution (Barber \& Odean, 2001; Beyer, 1998; Minter, Gruppen, Napolitano \& Gauger, 2005), risk-seeking (Charness \& Gneezy, 2012; Feng \& Seasholes, 2008; Hira \& Loibl, 2008; Powell \& Ansic, 1997) and overtrading (Agnew, Balduzzi, \& Sunden, 2003; Baker, 2010; Barber \& Odean, 2001).

\subsection{Overconfidence}

Overconfidence refers to a human being, being egoistic, strongly believing that their chosen actions are essential in the further advancement of their goal (Friedrichs \& Opp, 2002), or overestimating his or her own skills and chances of success (Rammstedt \& Rammsayer, 2002). In an experiment administered to 1359 subjects in the United States, Estes and Hosseini (1988) developed a model for estimating confidence in investment decisions and discovered that when making such decisions, women's confidence was lower than men's. A decade later, a study performed by Powell and Ansic (1997), in which participants earned remuneration dependant on a contingent outcome, was followed by a survey in order to assess the participants' responses. The results showed that women felt less confident at the beginning of the study and were more disposed to attribute any good performance to luck. This was found regardless of their prior experience or education. Irrespective of the consideration the participants earned from the study, no difference was found between their perceptions of their performance.

Hira and Loibl (2008) learnt that men are more confident in their knowledge and investing ability and are more likely to make investment changes when they found that their investments did not deliver the returns that they were expecting. Upon analysing the buys, sells, and holds of individuals and institutions in the Finnish stock market on a daily basis, Grinblatt and Keloharju (2009) realised that overconfident investors were more disposed to sensation seeking and thus traded more regularly. This excessive trading has been found to negatively affect performance (Odean, 1998). However, Glaser and Weber (2014) reported that overconfidence is not solely responsible for influencing trading behaviour.

Barber and Odean (2001) found that women perform better than men in their individual stock investments owing to men trading more and incurring friction costs as a result of their overconfidence. This behavior was characterised by Subrahmanyam (2008) as being akin to prehistoric human existence where men were required to be overconfident and take on risk when hunting in order to survive.

\subsection{Self-Efficacy And Self-Attribution Bias}

Self-efficacy relates to an individual's belief in his or her own competence (Busch 1995). Self-attribution bias is a phenomenon whereby humans tend to attribute any successful outcomes to skill and any unsuccessful outcomes to bad luck (Hirshleifer \& Ying Luo, 2001).

Men have been found to have a more favourable self-perception of their capabilities than women in a number of different areas such as mathematics (Rammstedt \& Rammsayer, 2002), computing and marketing knowledge (Busch, 1995), cognitive ability (Rammstedt \& Rammsayer, 2002) and financial decision making (Barber \& Odean, 2000 \& 2001). However, empirical results do not support this presumption. Conventional intelligence (i.e. IQ) has not been found to differ between men and women, and only in the field of mathematics have men been found to outperform women (Endres et al., 2008).

Endres et al. (2008) noticed that men and women are different in the way in which they perceive their own abilities and when setting personal goals to predict future performance. Men's goals were considerably more challenging than women's (Endres et al., 2008), which could have an effect on their investment decisions and 
ultimate performance. Barber and Odean (2001) noticed that while both men and women expect that they will outperform the market with their portfolios, men expect that they will outperform to a greater extent.

Women have been found to underestimate their abilities more than men, and this difference is more pronounced in tasks which are perceived to be more male-specific. Investing is an example of an environment which is more male-specific as it has historically been dominated by males (Barber \& Odean, 2001). It follows that a woman's perception of her own ability might be even lower in a task such as investing because when women perform a task well, that they attribute it to good luck, whilst men attribute it to their skill (Minter et al., 2005). However, when women perform a task poorly, they attributed it to their lack of skill, whilst men attributed it to bad luck (Minter et al., 2005). Women were also found to be more likely to remember their mistakes and, as such, were shown to have a stronger negative recall bias (Beyer, 1998). With the self-serving attribution bias being more apparent in men, it follows that men are more overconfident than women when it comes to investing (Barber \& Odean, 2001).

\subsection{Risk Seeking}

Men have been found to buy riskier stocks than women (Feng \& Seasholes, 2008), whilst women have been found to make smaller investments in risky assets and consequently appear to be more risk averse (Charness \& Gneezy, 2012). A significant determining factor of investment behavior is an individual's risk tolerance level; Hira and Loibl (2008) learnt that $51 \%$ of men preferred taking on risk to earn above-average returns, whilst $69 \%$ of women preferred taking average, below-average or no risks with their investments.

By using a cross-sectional Survey of Consumer Finances between 1983 and 2001, which encompassed a total of 24,037 households, Yao \& Hanna (2005) investigated risk tolerance and noted that significant differences existed in the risk tolerances of married and single men and women. Risk tolerance was noted to be the highest for single males, then married males, then unmarried females and lastly married females.

In an experimental study by Eckel and Grossman (2008), visual clues obtained by subjects in their observation of one another were used when assessing the risk preferences of others; women were perceived to be significantly more risk averse than men. The results were consistent regardless of whether men or women were making these predictions, which suggests stereotyping of men and women (Eckel \& Grossman, 2008). Schulman et al. (1999) showed that doctors are less likely to prescribe an aggressive form of treatment for female patients than they would for male patients with the same symptoms, owing to this stereotypical perception. This stereotype could have a direct bearing on men and women's self-perception and resultant investment decisions.

Men are more likely to interpret a risky situation as a challenge, whilst women are likely to perceive the same risky situation as a threat (Croson \& Gneezy, 2009). In a challenging environment men are stimulated at the thought of their ego and more inclined to engage in such a situation (Block, 1983), whilst women are more averse to competition. The competitiveness of an environment results in increased participation by men and lesser participation by women. However, these differences are weakened by type of profession and experience.

Harbaugh et al. (2002) were unable to find any consistently significant evidence of gender differences in risk aversion. Furthermore, whilst studying the performance of female mutual fund managers, Atkinson, Baird and Frye (2003) concluded there were no differences between men and women as to risk and fund performance.

Self-efficacy is positively associated with risk-taking and the literature shows that individuals with a higher belief in their own competence will steer towards taking more risks than those with a lower perceived capability (He et al., 2008). 


\subsection{Overtrading}

Agnew et al. (2003) investigated the trading behavior of 401(k) investors and observed men investing more in equities and trading more actively than women. Men traded 56\% more than women, while the average annual number of trades was 0.28 for men and 0.18 for women.

Barber and Odean (2001) noticed that women held slightly smaller common stock portfolios than men $(\$ 18,371$ vs. $\$ 21,975)$, and that women turned their portfolios only 0.53 times annually in comparison to men who turned theirs 0.77 times annually.

Feng and Seasholes (2008) investigated whether a man or a woman would sell a stock first if they both held the same stock and observed that men were $20.73 \%$ more likely to sell first. This result amplified by the result provided by Barber and Odean (2001) who found that men traded $45 \%$ more than women.

Odean (1998) concluded that overconfident traders will believe in a security more than they should and that they will subsequently trade more than could be expected of the theoretical 'rational' trader. Consequently, traders reduce their expected utility. Barber and Odean (2000) investigated households with accounts at a large discount brokerage house from 1991 to 1996 and noticed that those investors who traded the most earned an annual return of $11.4 \%$ (below the comparable market return of $17.9 \%$ ) and concluded that individual investors pay a penalty when trading actively. These authors (2001) also found that both men and women reduced their returns through trading, but that men did so by 0.94 percentage points per year more than women. Further support for the observation that investors earn below-benchmark performance as a result of frequent trading is supplied by Baker (2010).

\subsection{Gender Differentials In Biases}

In the studies discussed above, gender is referred to as a human being's biological sex, but it is noteworthy that masculine characteristics can no longer be applied to men alone (Twenge, 1997). In a questionnaire-based study on students at the University of Vienna, Meier-pesti and Penz (2008) showed that men still reported a higher identification with masculine attributes than women did. These masculine attributes were found to influence the level of risk taking, whilst feminine characteristics showed no effect.

\subsection{Conclusion}

The literature reviewed for this study provides strong evidence for the existence of behavioral biases. The literature consistently shows that men are more overconfident than women, and that overconfidence leads to overtrading. Most existing research concludes that overtrading lowers returns, but there is insufficient consistent evidence to support this assertion. Within a South African context, no studies have been undertaken on these topics, and as such, an investigation in the South African market is required to make a contribution to the international body of knowledge available.

\section{DATA AND METHODOLOGY}

\subsection{Research Questions}

The literature review suggests that women are better investors than men inasmuch as previous studies indicate that women earn higher average returns than men.

The research questions for this study are as follows:

1. Does trading frequency influence investor return?

2. Do men trade more than women?

3. Do men earn lower returns than women? 
The null hypotheses are that trading frequency does not influence returns $\left(\mathrm{H}_{0,1}\right.$, and that there is no difference between men and women in either trading frequency $\left(\mathrm{H}_{0,2)}\right.$ or investment returns $\left(\mathrm{H}_{0,3)}\right.$.

\subsection{Research Approach}

A South African investment house with records of individual investor performance and limited demographic information was approached. The investment house offers collective investment schemes (commonly referred to as unit trusts) with various risk profiles to the retail investing public. Initial specifications were given to the investment house so as to enable them to extract information relating to the return earned over various periods, and the gender of individual investors invested in an equity fund.

Owing to capacity constraints at the investment house, return data per individual investor on a per fund basis was not available. However, data over a cross section of funds per investor was available. Since the focus of this research is whether or not overtrading results in lower returns, it makes little difference whether an investor is invested in equity or another form of fund as multiple fund holdings do not necessarily affect the investor's ability to trade. Furthermore, by focusing only on funds trading into and out of an equity fund, the extent of results obtainable would be limited.

Further capacity constraints revealed that data would only be available from 1 January 2007 to 31 December 2011 and that the shortest time period for which data could be extracted was three years. As the complete data set of five years was a long enough period for fluctuations in returns earned to be smoothed out, it was decided to create sub-periods, in the hope of drawing out more specific gender differences. The periods were measured over calendar years as follows: 1 January 2007 - 31 December 2009 (three years), 1 January 2008 - 31 December 2010 (three years), 1 January 2009 - 31 December 2011 (three years) and 1 January 2007 - 31 December 2011 (five years, being the complete data set).

The data included only non-advised individual investors and excluded all investments by organisations, staff and group retirement fund clients as these investments are likely to be advised. The particular emphasis on nonadvised investors is in order to allow for behavioral biases between men and women to manifest as opposed to distorting them with the effect of a financial advisor investing on behalf of a client of the opposite gender. This approach is consistent with Barber and Odean (2001).

\subsection{Trading Frequency}

Unique to this study, 'trading' was defined as 'switching' where an investor moves money between funds on the investment house's platform. A switch frequency count was performed which included all lump sum contributions and redemptions. Regular investments (i.e. debit orders) were excluded because often these are set-up at the inception of the investment and are executed automatically. It may be reasonable to assume that there is less explicit consideration given to these cash flows than to lump sum investments and redemptions, where the decision might be amplified by an assessment of factors such as market price fluctuations.

\subsection{Research Method}

For reasons of confidentiality and privacy, the data provided by the investment house was devoid of any individual investor details. The investment house used the South African identification numbers of individual investors to discern the age and gender of those investors and provided a list of the results of the return calculations performed for each investor to the authors. This data included 19,021 individual investor returns over the five year and three year periods described previously. Each return result was flagged as male or female.

The return, net of switching costs, was calculated using the traditional method for calculating an internal rate of return (IRR). The IRR is considered acceptable as it standardises the return by taking into account the effects of cash flows into and out of the collective investment schemes and by doing so accounts for the effect of cash 
injections and withdrawals on investment return. Owing to the fact that the timing of cash flows could well be differentiated between men and women, this could be a determining factor in differential outcome.

In instances where a calculated return was missing for one or more of the four periods examined, that observation was omitted from the analysis. After sorting all the data into the respective groupings by period, the sample sizes were as follows:

Table 1: Data And Sample Sizes

\begin{tabular}{cccc}
\hline Calendar period & No. Of Men & No. Of Women & Total Sample \\
\hline 1 January 2007 - 31 December 2009 & $6,184(52 \%)$ & $5,633(48 \%)$ & $11,817(100 \%)$ \\
1 January 2008 - 31 December 2010 & $6,988(53 \%)$ & $6,305(47 \%)$ & $13,299(100 \%)$ \\
1 January 2009-31 December 2011 & $6,494(52 \%)$ & $5,922(48 \%)$ & $12,416(100 \%)$ \\
1 January 2007-31 December 2011 & $6,184(52 \%)$ & $5,632(48 \%)$ & $11,816(100 \%)$ \\
\hline
\end{tabular}

\subsection{Limitations}

The study cannot control for the influence that spouses may have on one another's investment decisions. Furthermore, the data did not permit the determination of whether the spouse who opened the account is the one actually making the decisions and using the account. Owing to confidentiality of client information, this study is unable to distinguish between married and single investors. As such, the further insight available from such data is not considered in this study.

\section{RESULTS}

\subsection{Does Trading Frequency Influence Investor Return?}

The number of switches made over the five year period ending 31 December 2011 was correlated against investment returns earned over the same period. Data on switch frequency was only available for the total five year period.

Table 2: Correlation Between Switch Frequency And Return

\begin{tabular}{lccc}
\hline & Number Of Observations & Spearman's rho & P \\
\hline $0-84$ switches & 11,817 & -0.1012 & $<0.0001$ \\
$0-6+$ switches & 11,817 & -0.1016 & $<0.0001$ \\
\hline
\end{tabular}

A highly significant negative correlation $(p<0.0001)$ was found between the number of switches made by investors and their corresponding returns (Table 2). These results are consistent with findings by Barber and Odean (2000) and Barber and Odean (2001).

The distribution of switches (Figure 1) shows that $77 \%$ of investors made no switches during the five years ending 31 December 2011, and that $97 \%$ of investors made 6 switches or less. 


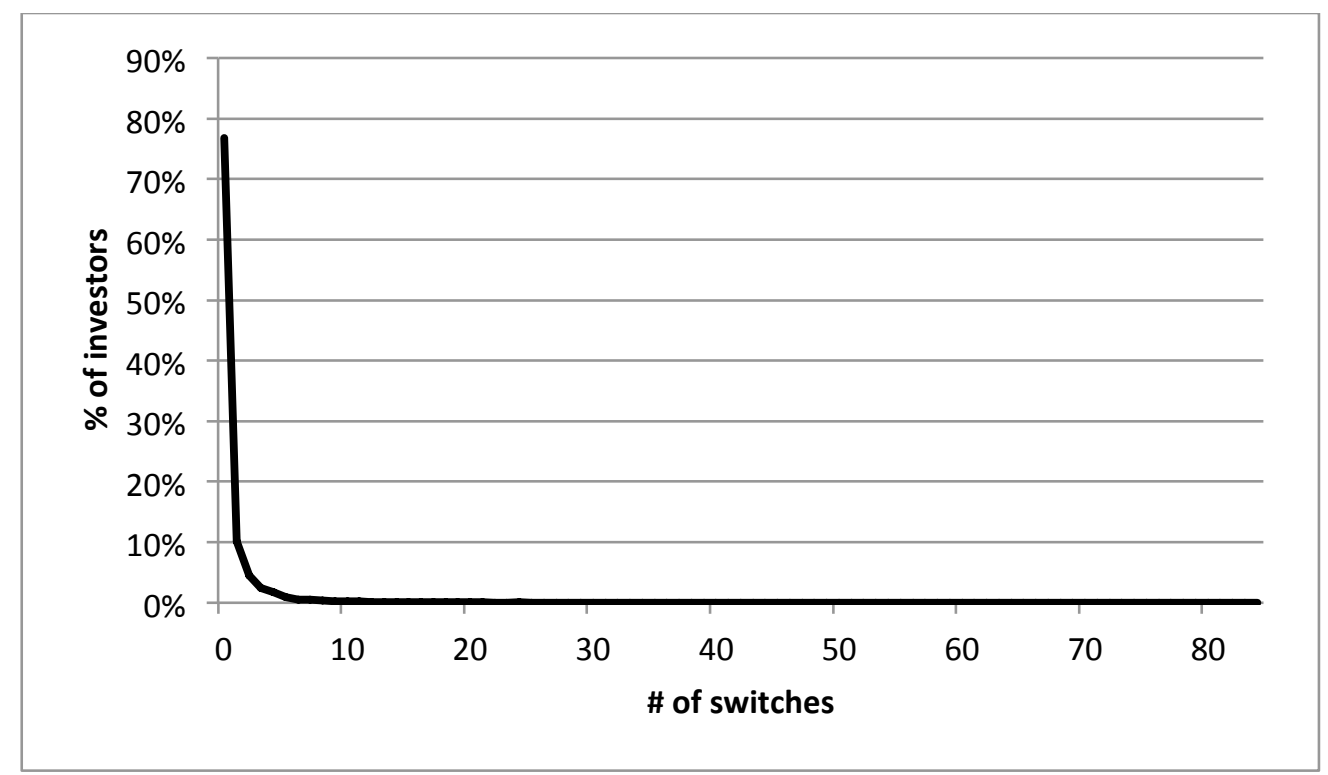

Figure 1: Distribution Of Switches

Consequently, the correlation test was re-performed having only six categories of switches i.e. $0,1,2,3,4$, 5 and $6+$ switches. Three percent of the total investors were grouped into the last cohort. The same highly significant negative correlation $(\mathrm{p}<0.0001)$ was found (Table 2$)$.

These results infer that trading frequency does indeed lower investment returns. This may be explained partially by two phenomena: friction (trading costs) and the effects of mistimed trades.

Barber and Odean (2001) support the effect of trading cost friction with their finding that men trade more and incur higher trading costs as a result of their overconfidence. As the return data in this study was calculated net of trading costs, it follows that lower returns would be observed for investors who traded more frequently.

The effects of buying overpriced assets and selling cheap assets is supported by Barber et al. (2009) who observed that stocks sold by individuals tended to outperform those that they bought. These mistimed investments resulted in lower returns. Barber et al. (2009) reasoned that affected investors trade speculatively owing to their overconfidence and want of entertainment.

\subsection{Do Men Trade More Than Women?}

A non-parametric Wilcoxon rank-sum test was used to test for any difference between the trading frequencies of men and women.

Table 3: Two-Sample For Mean Number Of Switches

\begin{tabular}{|c|c|c|c|c|c|c|}
\hline & $\begin{array}{c}\text { Number Of } \\
\text { Observations }\end{array}$ & Maximum & Mean & $\begin{array}{l}\text { Standard } \\
\text { Deviation }\end{array}$ & $\mathbf{Z}^{\mathrm{a}}$ & $\mathbf{P}$ \\
\hline Men & 6,184 & 84 & 1.02 & 4.07 & & \\
\hline Women & 5,633 & 68 & 0.68 & 2.58 & & \\
\hline Total & 11,817 & & & & $3.831^{\mathrm{b}}$ & 0.0001 \\
\hline
\end{tabular}

Men were found to trade significantly more than women $(\mathrm{p}<0.0001$, Table 3$)$ which is consistent with findings by Barber and Odean (2001) and Pompian and Longo (2004). 
Women were found to switch an average of 0.68 times over the five year period ending 31 December 2011, whereas men switched 1.02 times on average over the same period (Table 3). This finding is consistent with findings by Barber and Odean (2001) that annual stock portfolio turnover was 0.53 times and 0.77 times for women and men respectively.

\subsection{Do Men Earn Lower Returns Than Women?}

Given the sample sizes in question, the central limit theorem was applied. The population of returns earned by individual investors was inspected visually. Annexure A.1 to A.3 show distributions visually close to normal, whilst Annexure A.4 shows a distribution deviating from normal. As a result of this, the z-test is used for the first three periods and the Wilcoxon rank-sum test is used for the last period to test for the differences in returns between men and women (Table 4).

Table 4: Two Sample For Mean Return

\begin{tabular}{|c|c|c|c|c|c|}
\hline & & $\begin{array}{c}\text { Number Of } \\
\text { Observations }\end{array}$ & Mean & $\mathbf{Z}$ & $\mathbf{P}$ \\
\hline 5 years: & Men & 6,184 & 9.10 & & \\
\hline 1 January 2007 - & Women & 5,633 & 9.11 & & \\
\hline 31 December 2011 & Total & 11,817 & & $-0.126^{\mathrm{c}}$ & 0.45 \\
\hline 3 years: & Men & 6,988 & 7.80 & & \\
\hline 1 January 2007 - & Women & 6,305 & 7.96 & & \\
\hline 31 December 2009 & Total & 13,293 & & $-2.573^{c}$ & 0.005 \\
\hline 3 years: & Men & 6,494 & 7.03 & & \\
\hline 1 January 2008 - & Women & 5,922 & 7.11 & & \\
\hline 31 December 2010 & Total & 12,416 & & $-1.147^{\mathrm{c}}$ & 0.13 \\
\hline 3 years: & Men & 5,632 & 12.38 & & \\
\hline 1 January 2009 - & Women & 6,184 & 11.95 & & \\
\hline 31 December 2011 & Total & 11,816 & & $-8.608^{b}$ & $<0.0001$ \\
\hline
\end{tabular}

There was no statistically significant difference between the returns earned by men and women over the five year period ending 31 December 2011. The respective average annualised returns of men and women were $9.10 \%$ and $9.11 \%$.

Over two of the three-year periods (ending 31 December 2009 and 2010) women earned higher average returns than men at confidence levels of $99 \%$ (men: $7.80 \%$ per annum, women: $7.96 \%$ per annum) and $85 \%$ respectively (men: $7.03 \%$ per annum, women: $7.11 \%$ per annum) (Table 4 ).

However, for the three-year period ending 31 December 2011, men were found to earn higher returns $(12.38 \%$ per annum) than women $(11.95 \%$ per annum) at a high level of significance $(\mathrm{p}<0.0001$, Table 4$)$.

Whilst this study confirms that overtrading lowers returns and that South African men trade more than women, the results do not show with any statistical significance that South African men earn lower returns than women. However, Barclay, Litzenberger and Warner (1990) showed that the higher the trade frequency, the greater the variance in returns. From this, there is reason to consider that men could have a larger variability in their return, which would allow for the comparison of the risk-adjusted returns of men and women. This will be investigated by comparing the variance in return of men and women respectively. 


\subsection{Variance in return}

F-tests performed on the data in all four time periods examined show that men have significantly higher variances in return than women $(\mathrm{p}<0.0001$, Table 5).

Table 5: Two Sample For Variance In Return

\begin{tabular}{|c|c|c|c|c|c|c|}
\hline & & Observations & Mean & $\mathbf{F}$ & $\mathbf{P}$ & Variance \\
\hline 5 years: & Men & 6,184 & 9.10 & & & 8.76 \\
\hline \multirow{2}{*}{$\begin{array}{l}1 \text { January } 2007 \text { - } \\
31 \text { December } 2011\end{array}$} & Women & 5,633 & \multirow[t]{2}{*}{9.11} & & & \multirow[t]{2}{*}{5.4} \\
\hline & Total & 11,817 & & $1.621^{\mathrm{d}}$ & $<0.0001$ & \\
\hline 3 years: & Men & 6,988 & 7.80 & & & 15.82 \\
\hline \multirow{2}{*}{$\begin{array}{l}1 \text { January } 2007 \text { - } \\
31 \text { December } 2009\end{array}$} & Women & 6,305 & \multirow[t]{2}{*}{7.96} & & & \multirow[t]{2}{*}{12.18} \\
\hline & Total & 13,293 & & $1.299^{\mathrm{d}}$ & $<0.0001$ & \\
\hline 3 years: & Men & 6,494 & 7.03 & & & 18.46 \\
\hline \multirow{2}{*}{$\begin{array}{l}\text { January } 2008 \text { - } \\
31 \text { December } 2010\end{array}$} & Women & 5,922 & \multirow[t]{2}{*}{7.11} & & & \multirow[t]{2}{*}{11.75} \\
\hline & Total & 12,416 & & $1.571^{\mathrm{d}}$ & $<0.0001$ & \\
\hline 3 years: & Men & 5,632 & 12.38 & & & 15.93 \\
\hline \multirow{2}{*}{$\begin{array}{l}1 \text { January } 2009- \\
31 \text { December } 2011\end{array}$} & Women & 6,184 & \multirow[t]{2}{*}{11.95} & & & \multirow[t]{2}{*}{13.14} \\
\hline & Total & 11,816 & & $1.212^{\mathrm{d}}$ & $<0.0001$ & \\
\hline
\end{tabular}

Markowitz (1952) set out how, given the choice of two portfolios which earn the same return, a 'rational investor' would choose the one which presents the lowest risk or variance in return.

Given this study's finding that the variability of male returns is statistically significantly higher than those of women, and given that the investment returns of men and women are not statistically different, it follows that the sample of women in this study earn better risk-adjusted returns than men.

\subsection{Analysis Of Results}

The distribution of returns earned by investors (Annexure A) appears to be normal over all periods except for the three-year period ending 31 December 2011. The non-normality in the aforementioned three year period could be as a result of the financial crisis which was prevalent at the end of 2008 and the beginning of 2009 (Annexure B). That investors tend to sell risky investments and invest the proceeds in less risky or apparently riskless assets during market crashes has been supported by a number of studies including Barber et al. (2009) and Odean (1998).

It is conceivable that female investors (having been shown previously to be risk-averse and less prone to trading) who had switched from risky assets into cash during this crisis period would have delayed trading into the risky asset class after the market recovery. However, males may have benefitted from the equity market increases as a result of their greater propensity to trade (into the risky asset class in this instance) and lower risk aversion (Annexure B). These hypothesised actions might explain why men earned higher returns than women in the threeyear period ending 31 December 2011 (Table 4).

There is no statistically significant difference in the absolute returns earned by men and women. However, on the basis of return per unit of risk, women outperform men given the statistically significantly lower variability of women's returns.

\section{SUMMARY, CONCLUSIONS AND RECOMMENDATIONS}

\subsection{Summary Of Results}

A statistically significantly negative correlation was found between the number of switches made by investors and their corresponding returns and men were found to trade statistically significantly more than women. 
No statistically significant difference was found between the returns earned by men and women over the three and five year periods tested, except in the following instances:

- $\quad$ For the three year period ending 31 December 2009 women were found to statistically significantly outperform men.

- $\quad$ Seemingly aberrantly, for the three year period ending 31 December 2011 men were found to statistically significantly outperform women. This result is potentially explained by the gender-specific trading behavior in the markets over the same period.

An analysis of the variances in returns earned by men and women showed that men have statistically significantly greater variances in returns than women.

\subsection{Conclusions}

Trading frequency lowers investors' returns, a phenomenon that the literature reviewed attributes to friction and the effects of mistimed trades. Investors should rather buy-and-hold than trade vigorously to maximise their returns.

Men trade more than women. However, no statistically significant difference was found in the absolute returns earned by men and women. Further analysis showed that men have a statistically significantly greater variance in returns than women. Owing to the lack of a significant difference in the average returns earned by men and women, the larger variability in returns displayed by men allows the inference that on a risk-adjusted basis, women are better investors.

\subsection{Recommendations}

This study reveals findings on investor behaviour within an emerging market. The finding that trading frequency is negatively correlated to investor return is relevant to management as a cautionary tale to investors who tend to regularly switch within and between funds. The approach taken by management to inform investors of behavioral biases should also be viewed differently dependent on the sex of the investor.

The data used in this study was devoid of any information reflecting whether an investor was married or single. An investor's marital status introduces the possibility that a husband could be investing on behalf of his wife or vice versa. Both scenarios again introduce the possibility of gender-switching. A data set including marital status and other variables (such as the presence of children in a household) could offer further scope to identify and explain any differential investment performance between the genders.

The potential explanation for men earning higher returns than women during the market recovery after the financial crisis of 2008/9 requires further analysis. A consideration of whether men perhaps perform better in bull markets while women perhaps perform better in bear markets could also be considered in order to further reveal the risk propensities and behaviors of both genders.

\section{AUTHOR INFORMATION}

Gizelle Willows is a Senior Lecturer of Accounting and doctoral candidate in Finance at the University of Cape Town, South Africa. Her research interests lie in the field of behavioral finance. Email: gizelle.willows@uct.ac.za (corresponding author)

Darron West is a Senior Lecturer of Finance and at the University of Cape Town, South Africa. His research interests lie in the fields of investment management, behavioral finance and tax law. Email: darron.west@uct.ac.za 


\section{REFERENCES}

1. Agnew, J., Balduzzi, P., \& Sunden, A. (2003). Portfolio Choice and Trading in a Large 401 ( k ) Plan. The American Economic Review, 93, 193-215.

2. Atkinson, S. M., Baird, S. B., \& Frye, M. B. (2003). Do Female Mutual Fund Managers Manage Differently? The Journal of Financial Research, XXVI(1), 1-18.

3. Baker, H. (2010). Individual Investor Trading. In Behavioral Finance: Investors, Corporations, and Markets (pp. 1-26).

4. Barber, B. M., Lee, Y.-T., Liu, Y.-J., \& Odean, T. (2009). Just How Much Do Individual Investors Lose by Trading? The Review of Financial Studies, 22(2), 609-632.

5. Barber, B. M., \& Odean, T. (2000). Trading Is Hazardous to Your Wealth: The Common Stock Investment Performance of Individual Investors. The Journal of Finance, LV(2), 773-806.

6. Barber, B. M., \& Odean, T. (2001). Boys will be Boys: Gender, Overconfidence, and Common Stock Investment. The Quarterly Journal of Economics, 116(1), 261-292.

7. Barclay, M. J., Litzenberger, R. H., \& Warner, J. B. (1990). Private Information, Trading Volume, and StockReturn Variances. The Review of Financial Studies, 3(2), 233-253.

8. Beyer, S. (1998). Gender Differences in Self-Perception and Negative Recall Biases. Sex Roles, 38(1), 103133.

9. Block, J. H. (1983). Differential Premises Arising from Differential Socialization of the Sexes: Some Conjectures. Child Development, 54(6), 1335-1354.

10. Busch, T. (1995). Gender Differences in Self-Efficacy and Academic performance among Students of Business Administration. Scandinavian Journal of Educational Research, 39(4), 311-318.

11. Charness, G. B., \& Gneezy, U. (2012). Strong Evidence for Gender Differences in Risk Taking. Journal of Economic Behavior and Organization, 83(1), 50-58.

12. Croson, R., \& Gneezy, U. (2009). Gender Differences in Preferences. Journal of Economic Literature, 47(2), 448-474.

13. Eckel, C. C., \& Grossman, P. J. (2008). Forecasting Risk Attitudes: An Experimental Study Using Actual and Forecast Gamble Choices. Journal of Economic Behavior \& Organization, 68(1), 1-17. doi:10.1016/j.jebo.2008.04.006

14. Endres, M. L., Chowdhury, S. K., \& Alam, I. (2008). Gender Effects on Bias in Complex Financial Decisions. Journal of Managerial Issues, 20(2), 238-254.

15. Estes, R., \& Hosseini, J. (1988). The Gender Gap on Wall Street: An Empirical Analysis of Confidence in Investment Decision Making. The Journal of Psychology, 122(6), 577-590.

16. Fama, E. F., \& French, K. R. (1992). The Cross-Section of Expected Stock Returns. The Journal of Finance, 47(2), 427-465.

17. Fama, E. F., \& Macbeth, J. D. (1973). Risk, Return, and Equilibrium: Empirical Tests. Journal of Political Economy, 81(3), 607-636.

18. Feng, L., \& Seasholes, M. S. (2008). Individual Investors and Gender Similarities in an Emerging Stock Market. Pacific-Basin Finance Journal, 16(1-2), 44-60.

19. Friedrichs, J., \& Opp, K. (2002). Rational Behaviour in Everyday Situations. European Sociological Review, $18(4), 401-415$.

20. Glaser, M., \& Weber, M. (2014). Overconfidence and Trading Volume. The Geneva Risk and Insurance Review, 32(1), 1-36.

21. Grinblatt, M., \& Keloharju, M. (2009). Sensation Seeking, Overconfidence, and Trading Activity. The Journal of Finance, 64(2), 549-578.

22. Harbaugh, W. T., Krause, K., \& Vesterlund, L. (2002). Risk Attitudes of Children and Adults: Choices Over Small and Large Probability Gains and Losses. Experimental Economics, 5(1), 53-84.

23. He, X. I. N., Inman, J. J., \& Mittal, V. (2008). Gender Jeopardy in Financial Risk Taking. Journal of Marketing Research, 45(4), 414-424.

24. Hira, T. K., \& Loibl, C. (2008). Gender Differences in Investment Behavior. In Handbook of Consumer Finance Research (J.J. Xiao,., pp. 253-270).

25. Hirshleifer, D., \& Ying Luo, G. (2001). On the Survival of Overconfident Traders in a Competitive Securities Market. Journal of Financial Markets, 4(1), 73-84. 
26. Markowitz, H. (1952). Portfolio Selection. The Journal of Finance, 7(1), 77-91.

27. Meier-pesti, K., \& Penz, E. (2008). Sex or Gender? Expanding the Sex-Based View by Introducing Masculinity and Femininity as Predictors of Financial Risk Taking. Journal of Economic Psychology, 29(2), 180-196.

28. Minter, R. M., D, M., Gruppen, L. D., Ph, D., Napolitano, K. S., A, B. B., \& Gauger, P. G. (2005). Gender Differences in the Self-Assessment of Surgical Residents. The American Journal of Surgery, 189(6), 647650.

29. Odean, T. (1998). Volume, Volatility, Price, and Profit When All Traders Are Above Average. The Journal of Finance, 53(6), 1887-1934.

30. Pompian, M. M., \& Longo, J. M. (2004). A New Paradigm for Practical Application of Behavioral Finance: Creating Investment Programs Based on Personality Type and Gender to Produce Better Investment Outcomes. The Journal Of Wealth Management, 7(2), 9-15.

31. Powell, M., \& Ansic, D. (1997). Gender Differences in Risk Behaviour in Financial Decision-Making: An Experimental Analysis. Journal of Economic Psychology, 18(6), 605-628.

32. Rammstedt, B., \& Rammsayer, T. H. (2002). Gender Differences in Self-Estimated Intelligence and their Relation to Gender-Role Orientation. European Journal of Personality, 16(5), 369-382.

33. Ritter, J. R. (2003). Behavioral Finance. Pacific-Basin Finance Journal, 11(4), 429-441.

34. Schulman, K. A., Berlin, J. A., Harless, W., Kerner, J. F., Sistrunk, S., Gersh, B. J., Dube, R., Taleghani, C. K., Burke, J. E., Williams, S., Eisenberg, J. M. \& Escarce, J. J. (1999). The Effect of Race and Sex on Physicians' Recommendations for Cardiac Catheterization. The New England Journal of Medicine, 340(8), 618-626.

35. Subrahmanyam, A. (2008). Behavioural Finance: A Review and Synthesis. European Financial Management, 14(1), 12-29.

36. Twenge, J. M. (1997). Changes in Masculine and Feminine Traits over Time: A Meta-Analysis. Sex Roles, 36(5), 305-325.

37. Yao, R., \& Hanna, S. D. (2005). The Effect of Gender and Marital Status on Financial Risk Tolerance. Journal of Personal Finance, 4(1), 66-85. 


\section{APPENDIX}

Appendix A: Visual Test For Normal Distribution

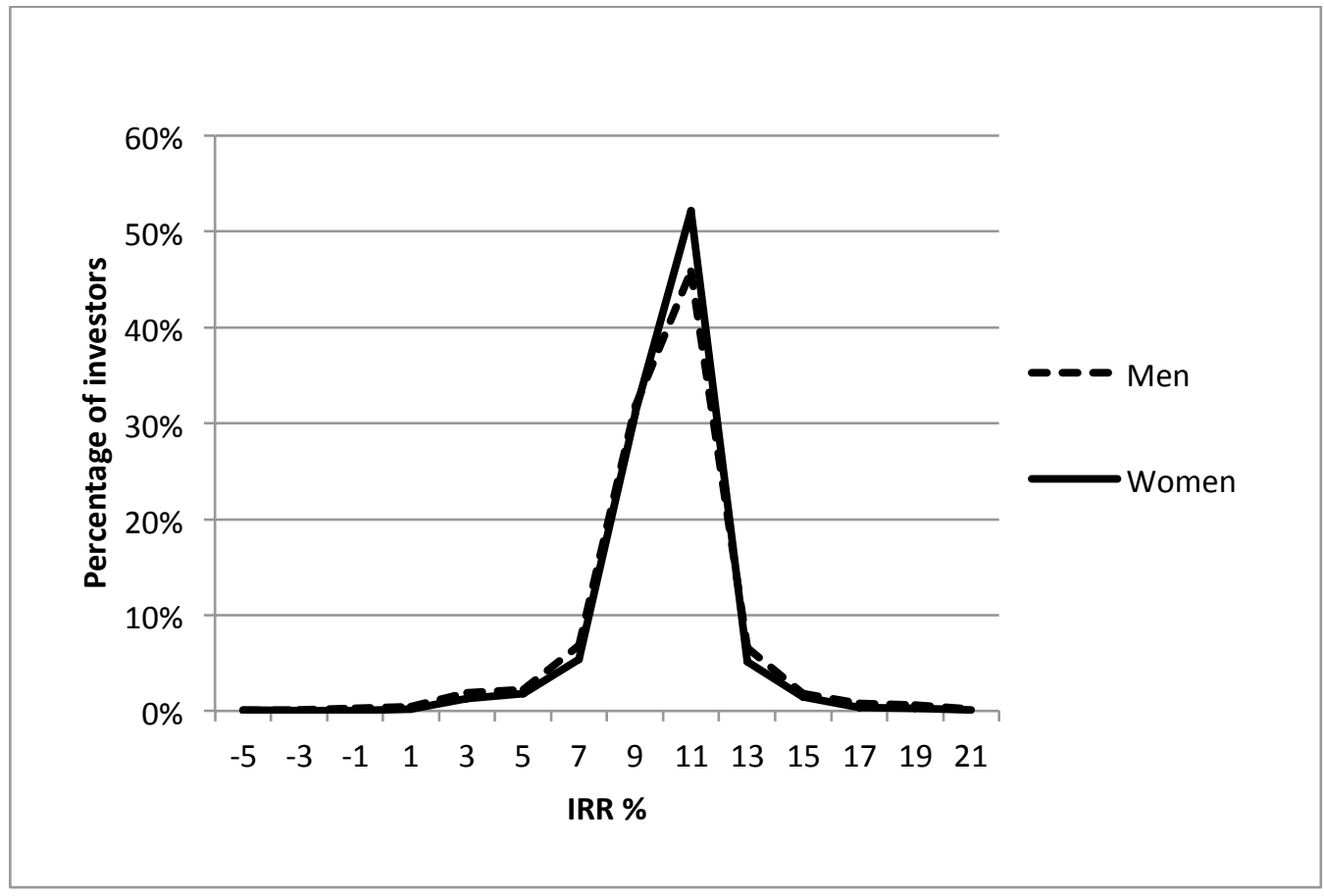

A.1: Investor Returns: Five Year Period 1 January 2007 To 31 December 2011

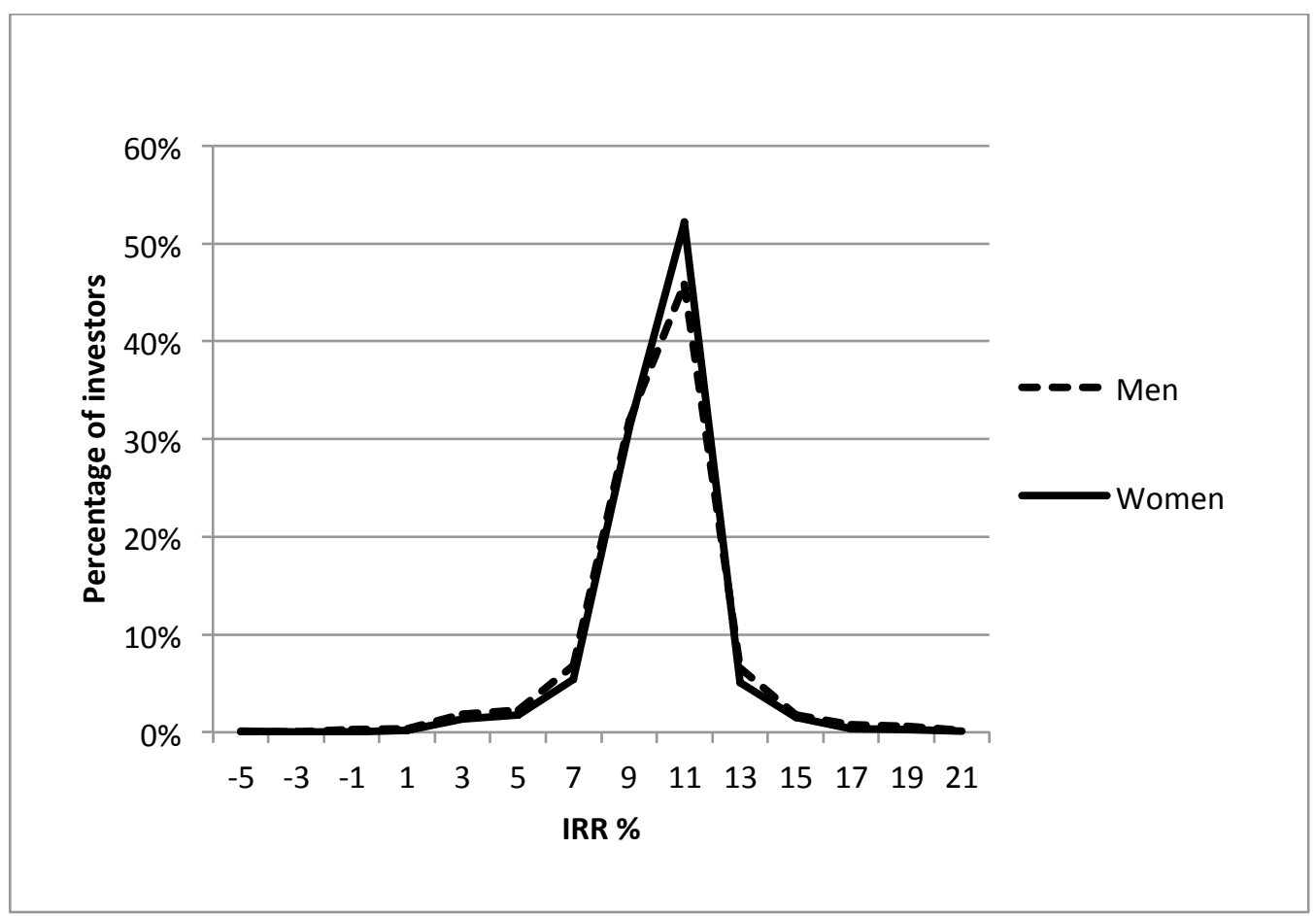

A.2: Investor Returns: Three Year Period 1 January 2007 To 31 December 2009 


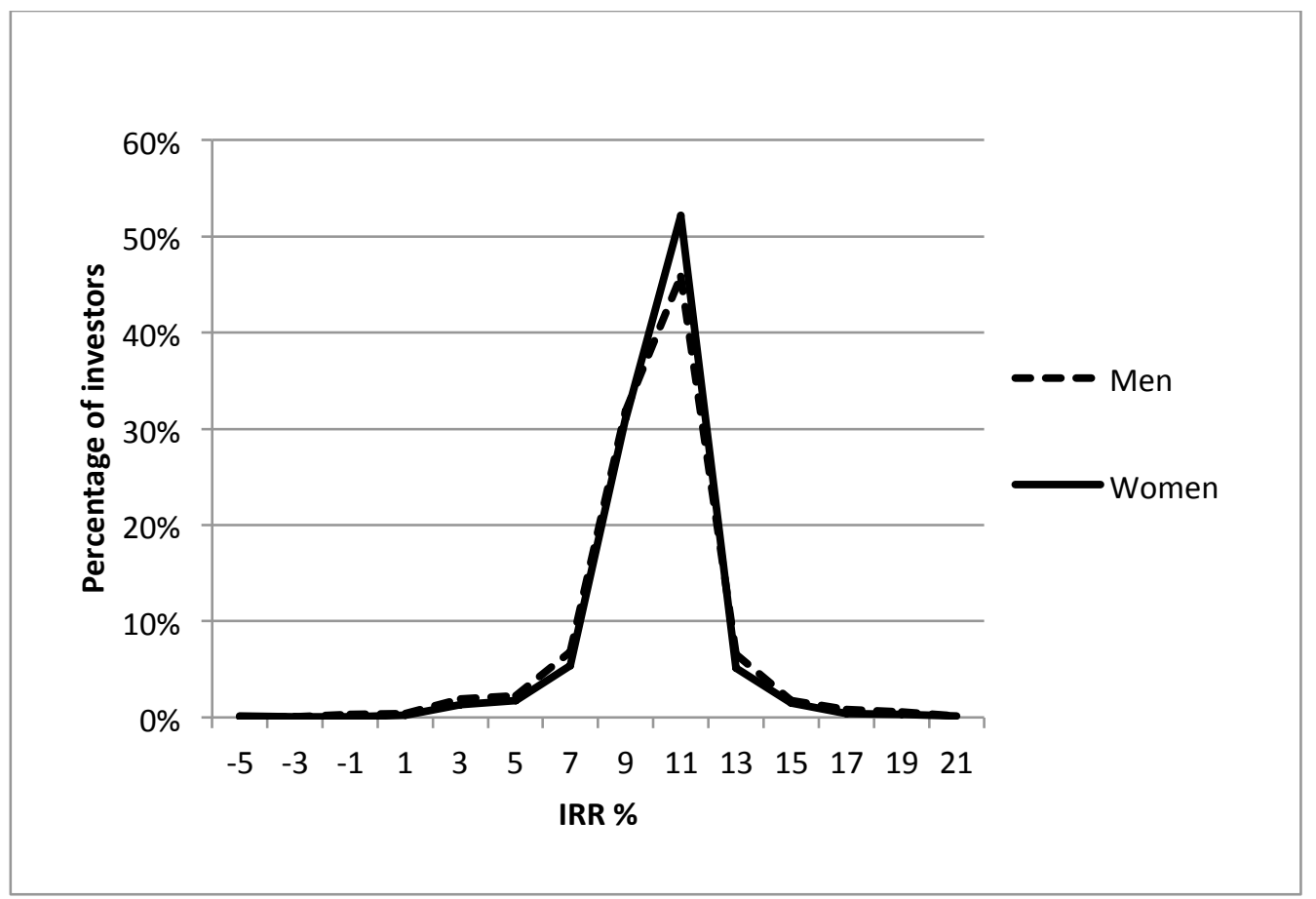

A.3: Investor Returns: Three Year Period 1 January 2008 To 31 December 2010

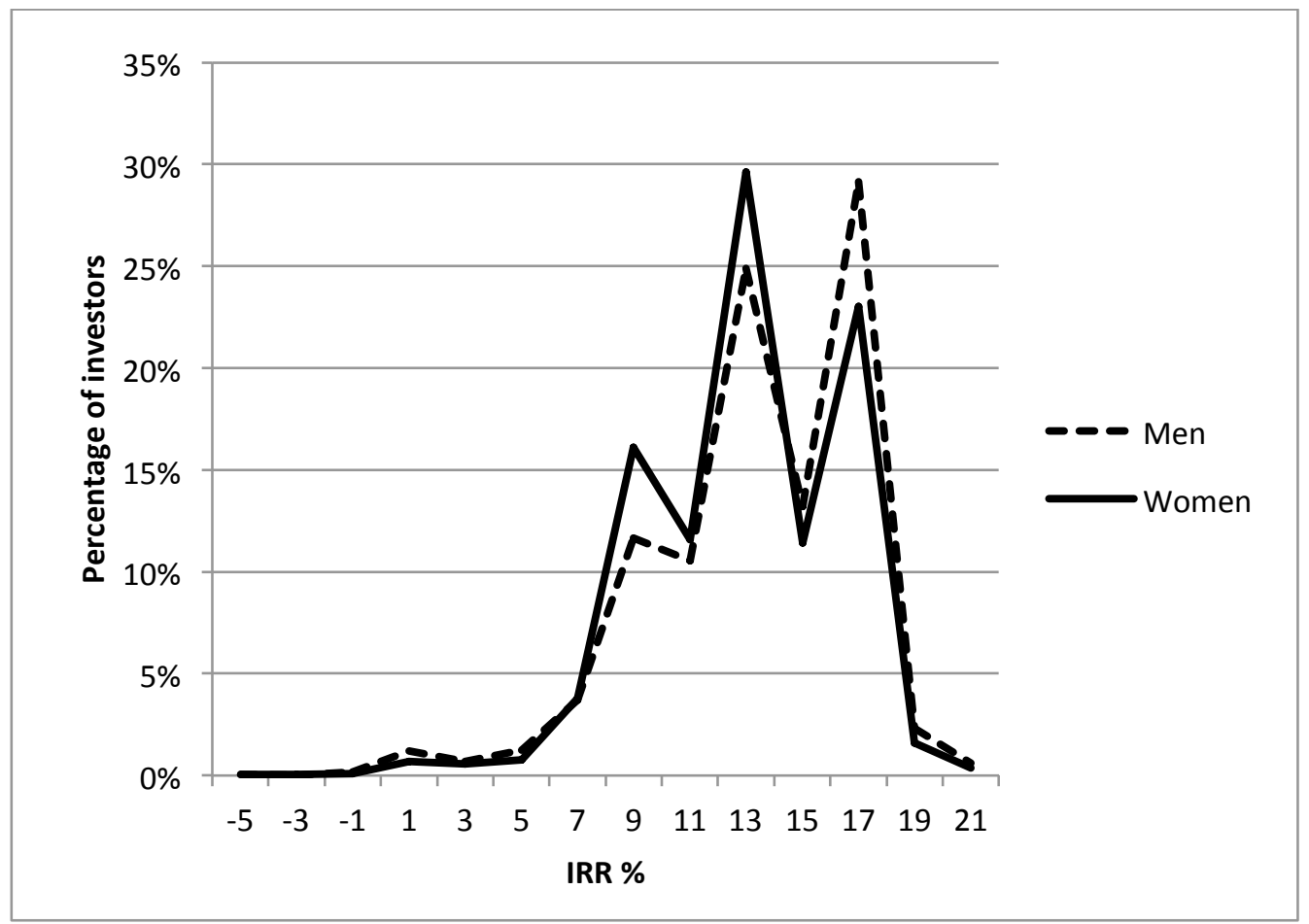

A.4: Investor Returns: Three Year Period 1 January 2009 To 31 December 2011 
Appendix B: Market Analysis

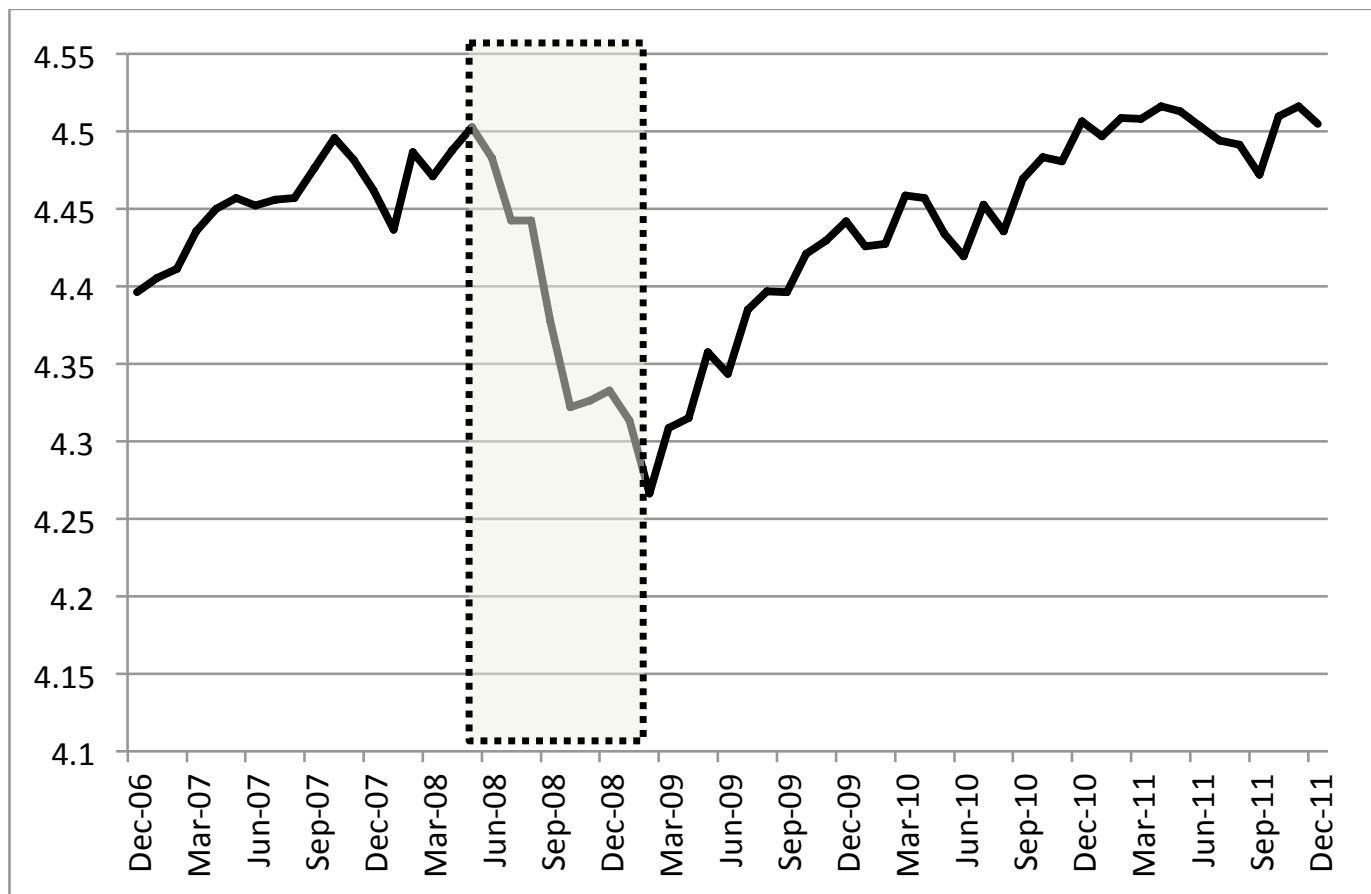

Appendix B: Jse All Share Index - 1 January 2007 - 31 December 2011 


\section{NOTES}

